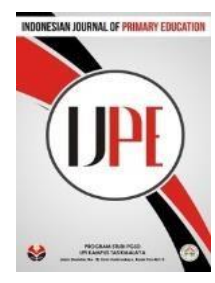

Vol. 1, No. 2 (2017) 83-94 ISSN: 2597-4866

Indonesian Journal of Primary Education

\title{
Pengaruh Model Pembelajaran Inquiry Berbantuan Media Games Book terhadap Hasil Belajar IPS dan Keterampilan Sosial Siswa SD
}

\author{
Acep Saepul Rahmat ${ }^{1}$, M. Syarif Sumantri ${ }^{2,}$, Deasyanti $^{3, *}$ \\ ${ }^{1}$ Program Pascasarjana Universitas Negeri Jakarta, Jl. Rawamangunmuka ,Jakarta Timur \\ ${ }^{2}$ Program Pascasarjana Universitas Negeri Jakarta, Jl. Rawamangunmuka ,Jakarta Timur \\ ${ }^{3}$ Program Pascasarjana Universitas Negeri Jakarta, Jl. Rawamangunmuka ,Jakarta Timur
}

*Corresponding author: acepsaepulrahmat@yahoo.com ; mohamadsumantri@gmail.com; deasy.edupsy@yahoo.com

Diterima 26 Oktober 2017; Direview 30 Oktober 2017; Diterima 12 November 2017

Diterbitkan online 21 Desember 2017

\begin{abstract}
Abstrak
Tujuan dari penelitian ini adalah untuk mengetahui pengaruh penerapan model pembelajaran Inquiry berbantuan media Games Book terhadap kemampuan hasil belajar IPS dan keterampilan sosial siswa kelas IV Sekolah Dasar. Penelitian dilakukan di SD Negeri Sukamanah 1 Kecamatan Cigalontang Tasikmalaya dengan sampel siswa kelas IVA 30 orang sebagai kelas eksperimen dan kelas IV B dengan sampel siswa 30 orang sebagai kelas kontrol yang dilaksanakan pada semester 1 tahun ajaran 2017/2018. Sampel yang digunakan dalam penelitian ini menggunakan random sampling. Teknik penelitian menggunakan metode eksperimen dengan desain quasi eksperimen. Teknik pengumpulan data dilakukan dengan menggunakan lembar tes hasil belajar kognitif dan lembar observasi pengamatan perilaku untuk mengetahui keterampilan sosial siswa pada saat proses pembelajaran Ilmu Pengetahuan Sosial, dengan terlebih dahulu dilakukan pengujian validitas dan realibilitas serta Justivication expert dan uji norrmalitas dan homogenitas baik kelas eksperimen yang menggunakan model pembelajaran Inquiry ataupun kelas kontrol yang menggunakan model pembelajaran ekspositori. Hasil pengujian menunjukan bahwa kedua kelas berdistribusi normal serta menunjukan homogenitas kedua kelas tersebut homeogen. Hasil penelitian menunjukan kenaikan rata-rata hasil belajar kognitif mata pelajaran IPS kelas eksperimen dari 51,66 menjadi 82,83 sedangkan kelas Kontrol dari 54,83 menjadi 60,13. Adapun aspek keterampilan sosial menunjukan skor rata-rata kelas eksperimen dari 51 menjadi dan 85 dari skor maksimal 120 dan keterampilan sosial untuk kelas kontrol memperoleh skor rata-rata dari 51,5 menjadi 59,5. serta keefektifan proses pembelajaran apabila melihat rata-rata Normal Gain kelas eksperimen lebih tinggi dibandingkan dengan kelas kontrol. Normal Gain hasil belajar kognitif untuk kelas eksperimen mendapatkan nilai 0,79 dengan kategori cukup efektif, sementara kelas kontrol mendapatkan kategori tidak efektif dengan nilai 0,27. Normal Gain keterampilan sosial kelas eksperimen menunjukan nilai 0,84 dan kelas kontrol dengan Normal Gain sebesar 0,36. Berdasarkan hasil penelitian tersebut, dapat disimpulkan hasil belajar kognitif dan keterampilan sosial siswa pada pembelajaran Ilmu Pengetahuan Sosial kelas eksperimen yang menerapkan model pembelajaran inquiry lebih baik dari pada belajar kognitif dan keterampilan sosial siswa pada pembelajaran Ilmu Pengetahuan Sosial kelas kontrol yang menerapkan metode pembelajaran ekspositori. Hal ini menyimpulkan bahwa terdapat pengaruh model pembelajaran inquiry terhadap hasil belajar dan keterampilan sosial siswa pada pembelajaran Ilmu Pengetahuan Sosial Sekolah Dasar.
\end{abstract}

Kata Kunci: Model Pembelajaran, Inquiry, Media, Games Book, Hasil Belajar, Keterampilan Sosial.

\section{PENDAHULUAN}

Proses pendidikan yang dilaksanakan di sekolah mengharapkan siswa dapat mengembangkan potensi terbaiknya sesuai dengan tujuan pembelajaran. Guru sebagai pengajar bukan hanya sekedar menyampaikan informasi terkait dengan materi pembelajaran, akan tetapi harus mampu menciptakan suasana kelas yang menyenangkan supaya siswa terlibat aktif dalam proses pembelajaran serta siswa dapat mengembangkan seluruh kemampuan yang ada pada dalam dirinya. Hal ini sejalan dengan UU No. 20 tahun 2003 tentang sistem pendidikan nasional, bahwa pendidikan adalah usaha sadar dan terencana untuk mewujudkan suasana belajar dan proses 
pembelajaran agar peserta didik secara aktif mengembangkan potensi dirinya untuk memiliki kekuatan spiritual keagamaan, pengendalian diri, kepribadian, kecerdasan, akhlak mulia, serta keterampilan yang diperlukan dirinya, masyarakat, bangsa dan negara.

Di setiap jenjang pendidikan khususnya di Sekolah Dasar, peserta didik diharuskan menempuh sejumlah mata pelajaran tertentu, diantaranya adalah mata pelajaran Bahasa Indonesia.

Dalam Peraturan Permendikbud No. 24 Tahun 2006 dijelaskan bahwasannya

"Ilmu Pengetahuan Sosial (IPS) merupakan salah satu mata pelajaran yang diberikan mulai dari SD/MI/SDLB sampai SMP/MTs/SMPLB. IPS mengkaji seperangkat peristiwa, fakta, konsep, dan generalisasi yang berkaitan dengan isu sosial. Pada jenjang SD/MI mata pelajaran IPS memuat materi Geografi, Sejarah, Sosiologi, dan Ekonomi. Melalui mata pelajaran IPS, peserta didik diarahkan untuk dapat menjadi warga negara Indonesia yang demokratis, dan bertanggung jawab, serta warga dunia yang cinta damai”.

Pada jenjang SD/MI mata pelajaran IPS memuat substansi materi meliputi pemahaman lingkungan, kejadian sosial, interaksi sosial, perekonomian serta kondisi ruang dan daerah. IPS mempunyai misi yang sangat esensial dan strategis yakni membentuk, mengembangkan, dan melatih siswa menjadi warga masyarakat, bangsa, dan negara yang mempunyai pengetahuan, pemahaman, dan keterampilan yang komprehensif sosial, sehingga mampu menjalani kehidupan masyarakat modern dan tataran kehidupan masyarakat global. Selain itu pula melalui mata pelajaran IPS diharapkan siswa diarahkan untuk menjadi seseorang yang mampu memiliki jiwa sosial yang tinggi, memiliki kemandirian, kreatif dan demokratis. Jarolimek mengemukakan bahwa pada dasarnya pendidikan IPS berhubungan erat dengan pengetahuan, keterampilan sosial, sikap, dan nilai-nilai yang memungkinkan siswa berperan serta dalam kelompok masyarakat di mana ia tinggal.

Sejalan dengan hal tersebut, Hosnan (2014) menjelaskan beberapa tuntutan pembelajaran abad 21 adalah mengarah pada 4C yang memuat Communication, Collaboration, Critical Thinking and Problem Solving dan Creativity and Innovation.

Siswa Sekolah Dasar memiliki karakteristik pemahaman yang bersifat operasional konkrit. Sesuai dengan apa yang dikemukakan oleh Piaget (dalam Susanto, 2013, hlm. 77). "Pada usia 7-11 Tahun siswa sudah mulai memahami aspek-aspek komulatif materi, memahami cara mengkombinasikan beberapa golongan benda yang bervariasi tingkatannya, serta berfikir sistematis mengenai benda-benda dan peristiwa -peristiwa yang konkrit".

Salah satu yang dapat dikembangkan 
untuk mencapai hal tersebut adalah dengan mengoptimalkan proses pembelajaran melalui penggunaan model pembelajaran interaktif dan komunikatif. Artinya desain pembelajaran yang mengaktifkan siswa dalam proses pembelajaran.

Model pembelajaran merupakan salah satu cara untuk mengatasi berbagai problematika dalam pelaksanaan pembelajaran.

Model pembelajaran inquiry banyak dikembangkan oleh para tokoh pakar pendidikan diantaranya adalah Suchman (1962). Suchman meyakini bahwasannya anak-anak merupakan individu yang penuh rasa ingin tahu akan segala sesuatu. (Ratni Sirait, 2012,h.254).

Hanafiah, 2009 dalam (Siti Masitoh, 2016,hlm.336) damengemukakan bahwa Inquiry merupakan rangkaian kegiatan pembelajaran yang melibatkan seluruh kemampuan siswa secara optimal untuk mencari dan menyelidiki secara sistematis, kritis dan logis sehingga dapat menemukan sendiri pengetahuan, sikap serta keterampilan siswa.

Keselman, 2003 dalam (Margus Pedaste,2015,hl,154) menyatakan bahwa Inquiry-based learning is an educational strategy in which students follow methods and practices similar to those of professional scientists in order to construct knowledge.

lkDalam mengembangkan model pembelajaran di kelas.Sumantri (2015) menyatakan bahwa
"Dalam mengajar, guru dapat mengembangkan model mengajarnya yang dimaksudkan sebagai upaya mempengaruhi perubahan baik dalam perilaku siswa, pengembangan modelmodel mengajar tersebut dimaksudkan untuk meningkatkan kemampuanya untuk lebih mengenal siswa dan menciptakan lingkungan yang lebih bervariasi bagi kepentingan belajar siswa."

Mulyasa (2012.hlm.108) menyatakan bahwasannya model pembelajaran Inquiry merupakan salah satu model pembelajaran yang mempersiapkan peserta didik pada situasi untuk melakukan eksperimen sendiri secara luas, melihat apa yang terjadi, ingin melakukan sesuatu, mengajukan pertanyaan, mencari jawaban sendiri, serta menghubungkan penemuan satu dengan penemuan lain.

Eruce dan Weil dalam (Hosnan, 2014, hlm. 346) model pembelajaran Inquiry dapat menambah pengetahuan sains, menghasilkan kemampuan berpikir kreatif, keterampilan serta dalam memperoleh suatu data atau konsep. Sedangkan Nasution (2005,hlm.128), menyatakan bahwa model pembelajaran Inquiry adalah merupakan proses belajar yang memberikan kesempatan pada siswa untuk menguji dan menafsirkan problema secara sistematika yang memberikan konklusi berdasarkan pembuktian.

Sanjaya (2006,hlm.43) menambahkan bahwa model pembelajaran inquiry adalah suatu model pembelajaran yang menekankan 
pada proses berpikir secara kritis dan analitis untuk mencari dan menemukan sendiri jawaban dari suatu permasalahan yang dipertanyakan.

Sebuah model pembelajaran dapat memanfaatkan media pembelajaran dengan tujuan memperlancar proses pelaksanaan tahapan model pembelajaran itu sendiri. Dalam pembelajaran dengan model pembelajaran Inquiry, guru menyajikan bahan berupa media dan sumber ajar untuk dapat membuat siswa menemukan pemahaman secara sendiri dan mandiri.

Dalam pelaksanaannya dalam pembelajaran, perlu diketahui beberapa tahapan (sintax) dari sebuah model pembelajaran. Adapun langkah-langkah model pembelajaran Inquiry menurut Hamdayana (2014) yaitu : 1.) Orientasi Pembelajaran dan pemberian konsep dasar pembelajaran; 2.) Merumuskan masalah; 3.) Merumuskan hipotesis; 4.) Mengumpulkan data; 6.) Menguji hipotesis dengan tindakan pembelajaran; 7.) Merumuskan kesimpulan; Menarik konsep dan kesimpulan umum.

Guru sebagai peneliti pula perlu memahami beberapa prinsip, karakteristik dan menganalisis beberapa hal penting yang mendukung terlaksananya pembelajaran inquiry, baik melalui pemanfaatan sumber belajar, media, strategi pembelajaran ataupun teknik penataan managemen kelas. Untuk itu dalam melaksanakan model pembelajaran Inquiry guru seyogyanya dapat memanfaatkan media pembelajaran sebagai salah satu cara untuk melaksanakan model pembelajaran.

Games Book merupakan salah satu media pembelajaran yang di desain dengan tujuan untuk menyampaikan materi melalui konsep permainan. (Rahmat, 2017,hlm.29)

Media alternatif ini menyajikan materi dalam bentuk permainan guna memberikan motivasi para siswa untuk terlibat aktif dalam proses pembelajaran. Permainan tersaji dalam sebuah buku yang di desain berisi berbagai macam permainan yang variatif, dan menantang. Setiap permainan relevan dengan tujuan pembelajaran serta berlandaskan atas standar kompetensi dan kompetensi dasar.

Games Book menyajikan berbagai macam permainan yang disajikan disertai dengan petunjuk penggunaan dan tata cara penyelesaian masalah. Setiap permainan disajikan berbagai persoalan dan pertanyaan terkait materi pembelajaran yang menuntut para siswa terlibat aktif untuk memecahkannya. Pemecahan masalah dilakukan dengan berbagai cara baik dengan cara berkelompok, mandiri ataupun campuran. Pada hakikatnya media ini menuntut adanya kerjasama antar siswa untuk dapat menyelesaikan setiap permainan.

Berdasarkan beberapa pandangan terkait model pembelajaran dan media pembelajaran yang inovatif dapat memberikan pembelajaran yang bermakna, maka hal ini relevan antara karakteristik siswa sekolah dasar, tuntutan pembelajaran abad 21 serta tujuan pembelajaran IPS yang satu sama lain 
saling berkesinambungan dengan penerapan model pembelajaran Inquiry dengan memanfaatkan media pembelajaran.

Melalui penerapan model pembelajaran Inquiry diharapkan tujuan pembelajaran dapat tercapai dengan maksimal. Mince Tonda, (2017,hlm.3) menyatakan bahwa model pembelajaran inquiry dapat memberikan peningkatan pada hasil belajar IPS siswa Sekolah Dasar.

Hasil penelitian

Dwidayani ,(2015,hlm.4) menyimpulkan bahwa penerapan model pembelajaran Inquiry dalam proses pembelajaran, dapat meningkatkan hasil belajar siswa pada mata pelajaran IPS pada siswa Sekolah Dasar.

Supardi , (2015, hlm.2) menyatakan bahwa hasil belajar pada dasarnya adalah terjadinya proses perubahan tingkah laku dari tidak tahu menjadi tahu, dari sikap yang kurang baik menjadi lebih baik, dan dari yang tidak terampil menjadi terampil.

Hasil belajar dapat membantu siswa untuk memecahkan permasalahan dalam hidupnya serta dapat menyesuaikan diri dengan lingkungan menuju perubahan kearah yang lebih positif. Pada prinsipnya hasil belajar merupakan suatu cerminan terhadap kemampuan individu setelah adanya proses pembelajaran. Bentuk hasil yang diperoleh dapat berupa angka, sikap dan keterampilan.

Bloom menjabarkan tipe hasil belajar terbagi atas 3 ranah yakni kognitif, afektif dan psikomotorik.Hasil belajar kognitif berhubungan dengan prestasi belajar siswa berupa pengetahuan, afektif lebih menekankan pada aspek sikap dan psikomotorik lebih menekankan pada aspek keterampilan. (Supardi, 2015, hlm.2)

Berdasarkan pandangan tersebut dapat disimpulkan bahwasannya hasil belajar tidak mengarah pada satu aspek saja, melainkan 3 aspek yang satu sama lain harus diperhatikan dalam proses pembelajaran. Dalam penelitian ini, peneliti lebih memfokuskan hasil belajar aspek kognitif yang diukur melalaui tes hasil belajar dan aspek afektif yang diukur dengan domain konatif yang fokus pada keterampilan sosial siswa.

Chaplin, dalam (Yulia, 2011,hlm5) menyatakan bahwa keterampilan sosial merupakan bentuk perilaku, perbuatan dan sikap yang ditampilkan oleh individu ketika berinteraksi dengan orang lain disertai dengan ketepatan dan kecepatan sehingga memberikan kenyamanan bagi orang yang berada disekitarnya. Senada dengan apa yang dikemukakan tersebut, (Gresham \& Elliott, 1990,hlm.6) yang mendefinisikan keterampilan sosial sebagai "Socially acceptable learned behaviors that enable an individual to interact effectively with others and to avoid or escape negative social interactions with others".

Lebih lanjut, Singleton (1983,hlm.283) menyatakan bahwasannya "social skills are closely related to the relationship of communication with others. There is evidence that communication has occurred when the recipient changed it behavior or attitude". 
Pandangan ini mengidentifikasikan keterampilan sosial kedalam bentuk perilaku interpersonal yang mencakup kemampuan individu untuk menjalin hubungan sosial dengan orang-orang di sekitarnya. Perilaku interpersonal yang dimaksud merupakan cerminan perilaku individu dalam memahami orang lain dalam konteks interaksi sosial. Hal ini sejalan dengan apa yang dikemukakan oleh Greene (2008,hlm.51) yang menyatakan bahwa

"Social skills lead to interpersonal behavior requiring complex communication skills of the younger generation, including interpreting social cues, recognizing how behaviors affect others, and understanding how one feels for others".

Anderman, (2009, hlm.3) mempertegas tentang keterampilan sosial yang menyatakan bahwa

"A large amount of evidence supports the role that children's social skills (including interpersonal behavior and learning-related skills) play in social and academic success.In general, children's interpersonal skills associated with social interaction include the ability to collaborate, communicate, social interaction and establish relationships with other individuals, whereas learningrelated skills have predicted academic.interpersonal skills are essential for social adjustment in childhood and adolescence. For example, one study found that poor interpersonal skills (eg, externalization problems) in childhood, predicts an academic problem in adolescence, which in turn causes internal problems in adulthood.

Gimpel \& Merrel,(1998,hlm.1) mengkarakteristikan keterampilan sosial sosial sebagai “....social skills are learned, composed of specific behaviors, include initiations and responses, maximize social reinforcement, are interactive and situationspecific, and can be specified as targets for intervention".

Berdasar karakteristik keterampilan sosial yang dikemukakan, maka untuk mempermudah mengenal dan memahami keterampilan sosial dalam proses pembelajaran perlu diketahui apa saja unsur yang ada dalam keterampilan sosial.

Sharon dan Simpon (2010,hlm.3) menyatakan bahwa "Social skills are behaviors that promote positive interaction with others and the environment. Some of these skills include showing empathy, participation in group activities, generosity, helpfulness, communicating with others, negotiating, and problem solving".

Pendapat tersebut senada dengan apa yang dikemukakan oleh Seefeldt dan Barbour (1994) dalam (Putri Admi,2013,hlm.337) yang menjelaskan keterampilan sosial terdari dari keterampilan komunikasi, berbagi (sharing), bekerja sama dan berpartisipasi dalam kelompok masyarakat. Selain dari itu, 
Sharon dan Simpon (2010,hlm.3 ) menjelaskan lebih rinci mengenai batasan yang ada dalam keterampilan sosial, sebagaimana pernyataannya bahwa:

"Social skills are behaviors that promote positive interaction with others and the environment. Some of these skills include showing empathy, participation in group activities, generosity, helpfulness, cooperation, communicating with others, negotiating, and problem solving”.

Gresham \& Elliot (1990) lebih lanjut menyatakan "...Major categories of social skill is communication, cooperation, assertion, responsibility, empathy, engagement dan self control."

Berdasarkan berbagai pandangan terkait unsur keterampilan sosial yang dikemukakan, maka terdapat beberapa kesamaan yang menjadi fokus dari keterampilan sosial. Peneliti menetapkan unsur keterampilan pandangan Sharon dan Simpon yang akan dijadikan aspek pengamatan keterampilan sosial.

Berdasarkan pendapat tersebut, keterampilan sosial erat kaitanya dengan perilaku interpersonal yang ditunjukan seseorang kepada individu lainya. Perilaku interpersonal ini memerlukan kemampuan untuk komunikasi yang dijadkan sebagai isyarat sosial, interaksi sosial, mengenali bagaimana perilaku, mempengaruhi orang lain, dan memahami bagaimana perasaan orang lain. Dengan demikian keterampilan sosial mengarah pada kemampuan individu untuk dapat melakukan komunikasi, interaksi, memahami perasaan orang lain serta menjalin kerjasama dengan individu lain. Keterampilan sosial diartikan sebagai keterampilan individu disertai dengan kecakapan dan keterampilan yang dimiliki anak dalam memulai aktivitas ataupun mempertahankan suatu hubungan yang positif dalam berinteraksi secara sosial dalam bentuk perilaku interpersonal yang dimana seseorang harus bisa berkolaborasi, berkomunikasi, berinteraksi sosial. dan membangun hubungan dengan orang lain.

Oleh karena itu, perlu adanya penerapan model pembelajaran yang inovatif dalam pembelajaran IPS yang diharapkan akan meningkatkan hasil belajar siswa serta menciptakan kondisi belajar yang lebih efektif, efisien dan menyenangkan, memberikan kesempatan kepada siswa untuk berperan serta aktif bertukar informasi dalam kegiatan kelompok, memiliki kepekaan terhadap lingkungan sosial, mampu bekerjasama dan bertanggung jawab.

\section{METODE}

Dalam Penelitian ini peneliti menggunakan pendekatan kuantitatif dengan metode penelitian eksperimen. Metode penelitian eksperimen adalah metode penelitian yang digunakan untuk mencari pengaruh perlakuan tertentu terhadap yang lain dalam kondisi yang terkendalikan. Sugiyono (2012, hlm.72). Desain penelitian yang digunakan oleh peneliti adal quasi eksperimen hal ini dimaksudkan karena tujuan dari penelitian ini adalah untuk mengukur 
sejauh mana pengaruh model pembelajaran Inquiry berbantuan media Games Book terhadap hasil belajar dan keterampilan sosial siswa pada pembelajaran Ilmu Pengetahuan Sosial materi sumber daya alam dan pemanfaatannya.

Adapun populasi dalam penelitian ini adalah siswa kelas IV A dan siswa kelas IV B SDN Sukamanah 1 Kecamatan Cigalontang Kabupaten Tasikmalaya dengan teknik sampel yang digunakan adalah teknik sampel jenuh. Sampel berjumlah 60 orang siswa kelas IV SDN Sukamanah 1 Kecamatan Cigalontang Kabupaten Tasikmalaya, dengan rincian 30 orang siswa kelas IV A sebagai kelompok eksperimen dan 30 orang siswa kelas IV B sebagai kelompok kontrol. Adapun desain yang digunakan adalah Nonequivalent Control Group Design. Instrumen penelitian terdiri dari tes, lembar angket, dan lembar observasi.

\section{HASIL DAN PEMBAHASAN}

Hasil penelitian ini berhubungan dengan pengaruh model pembelajaran Inquiry berbantuan media Games Book terhadap terhadap hasil belajar dan keterampilan sosial siswa pada pembelajaran Ilmu Pengetahuan Sosia materi sumber daya alam dan pemanfaatannya pada kelas IV SD Negeri Sukamanah 1 Kecamatan Cigalontang Kabupaten Tasikmalaya. Diadakannya penelitian ini, bertujuan untuk melihat pengaruh berupa hasil belajar dan keterampilan sosial setelah dilakukannya perlakuan model pembelajaran Inquiry pada kelas eksperimen dan metode ekspositori pada kelas kontrol. Dalam penelitian ini, terdapat dua kelas yang dijadikan sampel penelitian, dengan jumlah keseluruhan 60 orang siswa kelas SDN Sukamanah 1 Kecamatan Cigalontang Kabupaten Tasikmalaya, dengan rincian 30 orang siswa kelas IV A sebagai kelompok eksperimen dan 30 orang siswa kelas IV B sebagai kelompok kontrol

Berikut hasil analisis data yang telah dilakukan:

a. Analisis data kelas kontrol

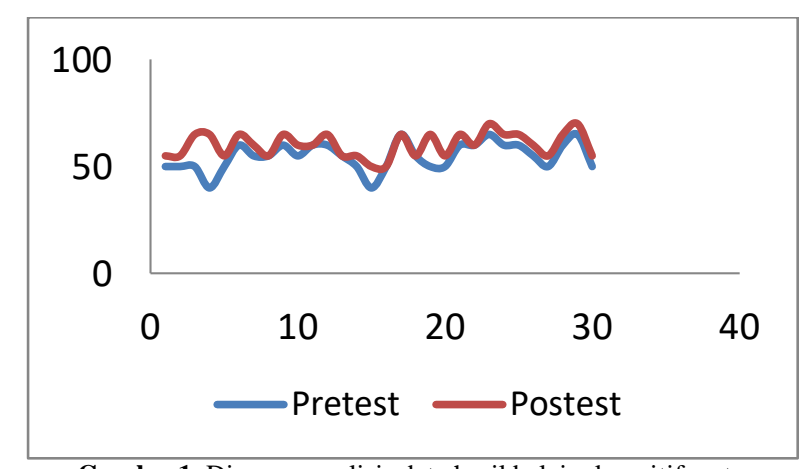

Gambar1. Diagram analisis data hasil belajar kognitif mata pelajaran Ilmu Pengetahuan Sosial kelas kontrol

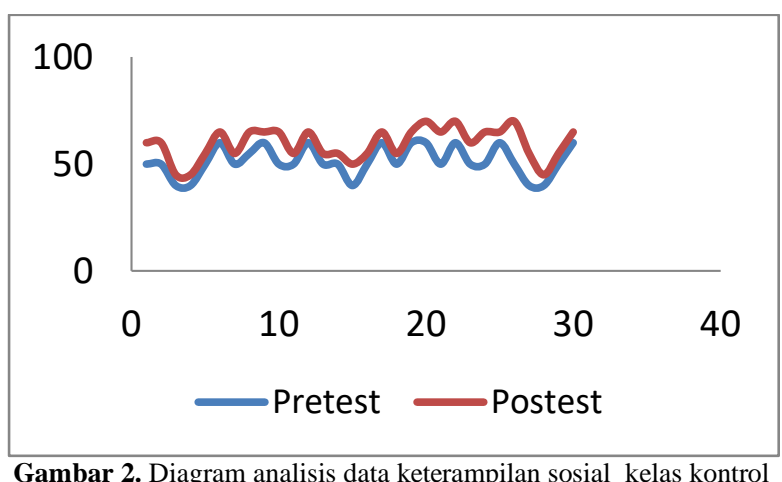

Dengan melihat gambar 1 terkait hasil belajar Ilmu Pengetahuan Sosial aspek kognitif (tes hasil belajar) dan gambar 2 keterampilan sosial siswa dalam proses pembelajaran Ilmu Pengetahuan Sosial, dapat diambil kesimpulan bahwa hasil belajar IPS awal siswa kelas kontrol tanpa menggunakan 
model pembelajaran Inquiry ( menggunakan model pembelajaran Ekspositori) dengan rata-rata nilai pretest 54,83 dan posttest 60,16 . Hal ini menunjukan tidak adanya kenaikan yang signifikan baik pada saat awal penelitian sampai akhir penelitian apabila dibandingkan dengan kelas eksperimen. Selanjutnya, gambar 2 yang menunjukan data keterampilan sosial siswa kelas kontrol didapatkan data pretest dengan skor bobot rata-rata 51,5 dari skor maksimal 120 dan posttest sebesar rata-rata 59,5 dari skor maksimal 120.berdasarkan analisis tersebut baik dari hasil belajar ips maupun keterampilan sosial kelas kontrol sama-sama belum menunjukan peningkatan yang signifikan.

\section{b. Analisis Data Kelas Eksperimen}
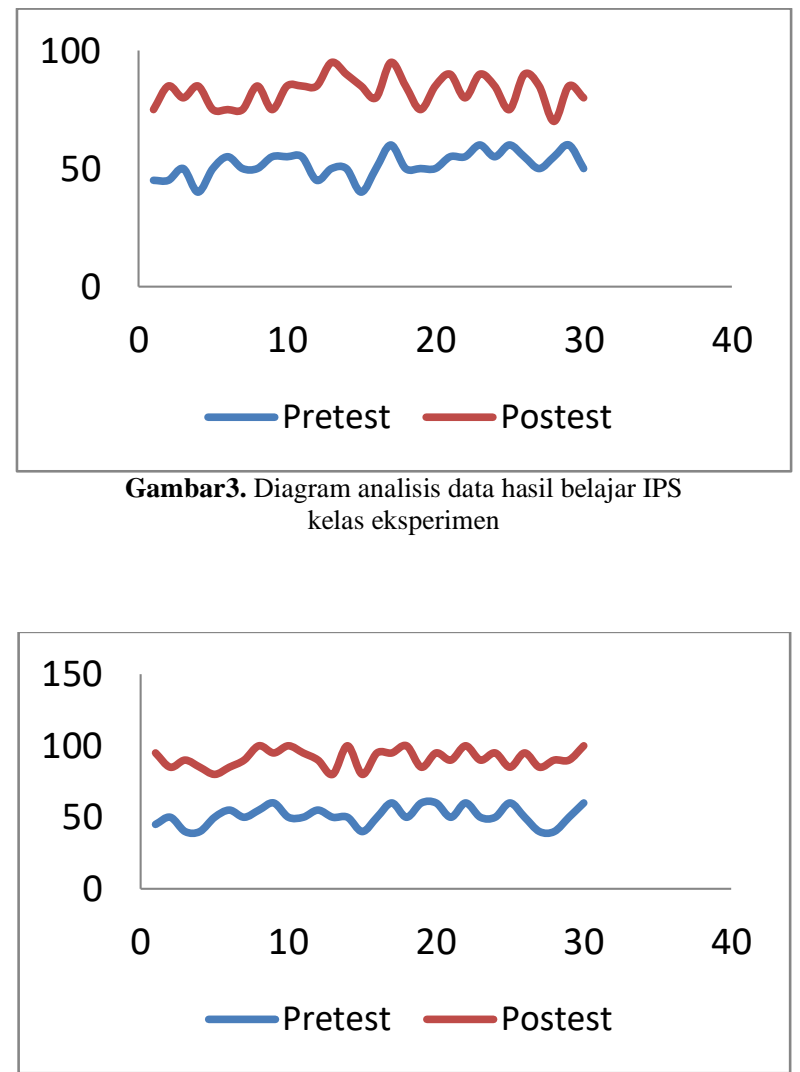

Gambar 4. Diagram analisis data keterampilan sosial kelas eksperimen
Dengan melihat gambar 3 terkait hasil belajar IPS kelas eksperimen sebelum perlakuan dan gambar 4 keterampilan sosial siswa dalam proses pembelajaran Ilmu Pengetahuan Sosial, dapat diambil kesimpulan bahwa hasil belajar IPS siswa kelas eksperimen dengan menggunakan model pembelajaran Inquiry dianalisis didapatkan data rata-rata nilai pretest 51,66 dan posttest 82,83. Hal ini menunjukan adanya kenaikan yang signifikan baik pada saat awal penelitian sampai akhir penelitian apabila dibandingkan dengan kelas kontrol. Analisis data awal sebelum perlakuan menunjukan hasil belajar IPS rata-rata dibawah nilai KKM, dan setelah adanya penerapan model pembelajaran Inquiry ratarata nilai hasil belajar IPS melampaui Kriteria Ketuntasan Minimal mata pelajaran IPS yang ditetapkan yakni 75. Hal ini menunjukan bahwa adanya pengaruh yang signifikan dari penerapan model pembelajaran Inquiry dalam proses pembelajaran Ilmu Pengetahuan Sosial.

Selanjutnya, apabila melihat data gambar 4 terkait data keterampilan sosial siswa kelas eksperimen setelah adanya perlakuan berupa penerapan model pembelajaran Inquiry dalam proses pembelajaran Ilmu Pengetahuan Sosial didapatkan data pretest (observasi sebelum perlakuan) dengan rata-rata mendapatkan bobot skor 55, dari skor maksimal 120 dan posttest (observasi pada saat proses penerapan model inquiry) mendapatkan bobot skor 
sebesar 91,5 dari skor maksimal 120. Hal ini menunjukan keterampilan sosial siswa kelas eksperimen dikategorikan Baik. Hal ini ditunjuukan dengan kondisi siswa pada saat penerapan model pemeblajaran inquiry terjailn komunikasi, kerjasama dan aktivitas pembelajaran yang aktif. Dengan data analisis tersebut dapat disimpulkan bahwasannya penerapan model pembelajaran inquiry dalam pembelajaran Ilmu Pengetahuan Sosial materi sumber daya alam dan pemanfaatannya berpengaruh signifikan pada peningkatan keterampilan sosial siswa sebelum dan sesudah perlakuan.

Analisis Perbandingan Hasil Belajar IPS dan Keterampilan Sosial Siswa Kelas Kontrol dan Kelas Eksperimen

\begin{tabular}{|c|c|c|c|c|c|}
\hline \multirow[b]{2}{*}{ Kelas } & \multirow{2}{*}{$\begin{array}{l}\text { Fokus } \\
\text { Penelitian }\end{array}$} & \multicolumn{3}{|c|}{ Nilai Rata-rata/Skor } & \multirow{2}{*}{$\begin{array}{l}\text { Kualitas } \\
\text { Hasil } \\
\text { Belajar }\end{array}$} \\
\hline & & Pretest & Posttest & $\begin{array}{l}\text { Normal } \\
\text { Gain }\end{array}$ & \\
\hline \multirow[t]{2}{*}{ Kontrol } & $\begin{array}{l}\text { Hasil Belajar } \\
\text { IPS (Tes hasil } \\
\text { belajar } \\
\text { kognitif) }\end{array}$ & 54,83 & 60,13 & 0,27 & $\begin{array}{l}\text { Tidak } \\
\text { Efektif }\end{array}$ \\
\hline & $\begin{array}{l}\text { Keterampilan } \\
\text { Sosial }\end{array}$ & 51,5 & 59,5 & 0,36 & $\begin{array}{l}\text { Tidak } \\
\text { Efektif }\end{array}$ \\
\hline \multirow[t]{2}{*}{ Eksperimen } & $\begin{array}{l}\text { Hasil Belajar } \\
\text { IPS (Tes hasil } \\
\text { belajar } \\
\text { kognitif) }\end{array}$ & 51,66 & 82,83 & 0,79 & $\begin{array}{l}\text { Cukup } \\
\text { Efektif }\end{array}$ \\
\hline & $\begin{array}{l}\text { Keterampilan } \\
\text { Sosial }\end{array}$ & 51 & 85 & 0,84 & $\begin{array}{l}\text { Sangat } \\
\text { Efektif }\end{array}$ \\
\hline
\end{tabular}

Dari tabel 1 di atas diketahui bahwa nilai rata-rata hasil belajar IPS pretest di kelas kontrol yaitu 54,83 sedangkan untuk nilai rata-rata untuk kelas eksperimen yaitu 51,66. Dilihat dari nilai rata-rata pretest yang menunjukan data yang hampir mendekati sama pada kelas kontrol. Hasil posttest hasil belajar IPS di kelas kontrol yaitu 60,13 sedangkan untuk kelas eksperimen yaitu 82,83. Hasil posttest pada kelas kontrol mendapat kategori rendah sedangkan dikelas eksperimen mendapat kategori tinggi.

Selanjutnya, skor atau nilai rata-rata keterampilan sosial pretest di kelas kontrol yaitu 51,5 sedangkan untuk skor nilai rata-rata untuk kelas eksperimen yaitu 51. Dilihat dari nilai rata-rata pretest pada kelas kontrol lebih tinggi nilai pretest dibandingkan kelas eksperimen. Hasil posttest ( pada saat pelaksanaan model pembelajaran inquiy di eklas eksperimen dan metode eskpositori di kelas kontrol) data keterampilan sosial di kelas kontrol yaitu 59,5, sedangkan untuk kelas eksperimen yaitu 85 dari skor maksimal keterampilan sosial 120. Hal ini membuktikan bahwa terdapat pengaruh yang signifikan dari penerapan model pemeblajaran inquiry dalam pembelajaran Ilmu Pengetahuan Sosial baik dari aspek hasil belajar kognitif maupun keterampilan sosial.

\section{KESIMPULAN}

Berdasarkan data-data yang terhimpun melalui data kualitatif dan kuantitatif maka dapat disimpulkan bahwa model pembelajaran Inquiry berbantuan media Games Book memberikan pengaruh terhadap hasil belajar IPS dan Keterampilan Sosial siswa pada pembelajaran Ilmu Pengetahuan Sosial. Hal ini terbukti dengan melihat nilai rata-rata dari kelas kontrol dan eksperimen SDN Sukamanah 1 Kecamatan Cigalontang Kabupaten Tasikmalaya, jika melihat efektivitas proses pembelajaran kelas eksperimen lebih baik dibandingakn kelas 
kontrol dengan kategori cukup efektif dan untuk kelas kontrol tidak efektif

Implikasi diadakannya penelitian dengan menggunakan model pembelajaran Inquiry berbantuan media Games Book terhadap pasrtisipan yaitu, adanya peningkatan hasil belajar IPS dan Keterampilan Sosial siswa pada pembelajaran pembelajaran Ilmu Pengetahuan Sosial baik melalui pemahaman, sikap, dan keterampilan siswa dalam proses pembelajaran.

Meningkatnya hasil belajar IPS dan Keterampilan Sosial siswa dapat dilihat dari peningkatan hasi pretest dan posttest yang dilakukan siswa.

\section{REFERENSI}

Hamdayana.(2014).Model dan Metode

Pembelajaran Kreatif dan

Berkarakter. Bogor: Ghalia Indonesia.

Hosnan. (2014). Pendekatan Saintifik dan Kontekstual dalam pembelajaran abad 21. Bogor: Ghalia Indonesia.

James Freeman. Developing Social Skills and Relationships. Reclaimingjournal. Winter, 2015 Volume 23, number 4, h.51.

Jhoni L Matson (2009). Social Behavior and Skills in Children. New York Dordrecht Heidelberg London: Springer.

M. Anderman.Social Skills. Jurnal Psychology of Classroom Learning.
Vol. 2. Detroit: Macmillan Reference USA, 2009. p843-847.

Margus Pedaste. Phases of Inquiry-based learning: Definitions and the Inquiry cycle.Jurnal Online : Elsevier, Procedia - Educational Research Review Vol. 14 (2015) 47-61 ISSN 1747-938X (C) 2015 Published by Elsevier Ltd.

Mince Tonda. Penerapan Model Pembelajaran Inquiry Untuk Meningkatkan Hasil Belajar IPS Siswa Kelas V SD.Jurnal Pendidikan Guru Sekolah Dasar Vol.1 Edisi 7,Tahun ke-6-Mei 2017.

Mulyasa, E.(2012).Menjadi Guru Profesional. Bandung: Remaja Rosdakarya.

Nasution. (2005). Berbagai Pendekatan Dalam Proses Belajar Mengajar.Jakarta: Bumi Aksara.

Ni Kadek Nanik Dwidayani. Meningkatkan Hasil Belajar Mata Pelajaran IPS Melalui Penerapan Model Inquiry Pada Siswa Kelas IV SD Inpres BajawaliKecamatan Lariang Kabupaten Mamuju Utara..Jurnal Kreatif Tadulako Online Vol. 3 No. 2ISSN 2354-614X

Putri Admi Perdani. Peningkatan Keterampilan Sosial Melalui Metode 
Bermain Permainan Tradisional

Pada Anak TK B. Jurnal

PENDIDIKAN Anak Usia Dini PPs

UNJ. Volume 7 Edisi 2, November 2013,h. 337.

Rahmat. Games Book sebagai Media Peningkatan Minat Baca pada Pembelajaran Bahasa Indonesia SD Kelas Tinggi. Jurnal IJPE UPI, Vol 1 No 1 (2017) 27-33.

Ratni Sirait. Pengaruh Model Pembelajaran Inquiry Training terhadap Hasil Belajar Siswa pada materi pokok usaha dan energi panas. Jurnal Pendidikan Fisika UNIMED, Vol.1, No.1, Juni 2012, ISSN: 2252-732X.

Sanjaya,Wina. (2006).Strategi Pembelajaran Berorientasi Standart Proses Pendidikan.Jakarta : Kencana Prenada Media.

Siti Masitoh. Peningkatan Hasil Belajar IPS Melalui Strategi Inquiry Discovery Learning Di Kelas IV SDN Kecamatan Cikarang Utara Kabupaten Bekasi. Jurnal Pendidikan Dasar UNJ. Vol.7 Edisi 2 Desember 2016- p-ISSN 20867433 , e-ISNN 2549-5801.

Sharon A. Lynch and Cynthia G. Simpson. Social Skills: Laying the Foundation for Success. Journal Spring/Summer. Volume 38, Number 2, 2010 , h.3.
Singleton.(1983). Social Skill: The Study og Real Skill. England: MTP Press Limited

Stephen N. Elliott. (2016).Social Skills Development in Early Childhood Enabling Learning, Growing Friends.USA:Learning Sciences Institute Arizona State University.

Supardi.(2015).Penilaian Autentik Pembelajaran Afektif, Kognitif dan Psikomotor. Jakarta: Rajawali Pers.

Yulia Siska. Penerapan Metode Bermain Peran dalam meningkatkan Keterampilan Sosial dan Keterampilan Berbicara Anak Usia Dini. Jurnal Pendidikan Dasar. Eds. Khusus No. 2 Agustus 2011- ISSN 1412-565X. 